\title{
Artificial Neural Networks (ANNs) and Response Surface Methodology (RSM) Approach for Modelling the Optimization of Chromium (VI) Reduction by Newly Isolated Acinetobacter radioresistens Strain NS-MIE from Agricultural Soil
}

\author{
Nur Syuhadah Ram Talib $\mathbb{D},{ }^{1}$ Mohd Izuan Effendi Halmi $\mathbb{D}^{1},{ }^{1}$ Siti Salwa Abd Ghani, ${ }^{2}$ \\ Uswatun Hasanah Zaidan, ${ }^{3}$ and Mohd Yunus Abd Shukor ${ }^{3}{ }^{3}$ \\ ${ }^{1}$ Department of Land Management, Faculty of Agriculture, Universiti Putra Malaysia, 43400 Serdang, Selangor, Malaysia \\ ${ }^{2}$ Department of Agricultural Technology, Faculty of Agriculture, Universiti Putra Malaysia, 43400 Serdang, Selangor, Malaysia \\ ${ }^{3}$ Department of Biochemistry, Faculty of Biotechnology and Biomolecular Sciences, Universiti Putra Malaysia, \\ 43400 Serdang, Selangor, Malaysia \\ Correspondence should be addressed to Mohd Izuan Effendi Halmi; m_izuaneffendi@upm.edu.my
}

Received 12 February 2019; Revised 16 April 2019; Accepted 30 April 2019; Published 26 May 2019

Academic Editor: Frederick D. Quinn

Copyright (C) 2019 Nur Syuhadah Ram Talib et al. This is an open access article distributed under the Creative Commons Attribution License, which permits unrestricted use, distribution, and reproduction in any medium, provided the original work is properly cited.

\begin{abstract}
Numerous technologies and approaches have been used in the past few decades to remove hexavalent chromium (Cr[VI]) in wastewater and the environment. However, these conventional technologies are not economical and efficient in removing Cr(VI) at a very low concentration (1-100 ppm). As an alternative, the utilization of bioremediation techniques which uses the potential of microorganisms could represent an effective technique for the detoxification of $\mathrm{Cr}(\mathrm{VI})$. In this study, we reported a newly isolated bacterium identified as Acinetobacter radioresistens $\mathrm{sp}$. NS-MIE from Malaysian agricultural soil. The chromate reduction potential of strain NS-MIE was optimized using RSM and ANN techniques. The optimum condition predicted by RSM for the bacterium to reduce hexavalent chromium occurred at $\mathrm{pH} 6,10 \mathrm{~g} / \mathrm{L} \mathrm{ppm}$ of nutrient broth $(\mathrm{NB})$ concentration and $100 \mathrm{ppm}$ of chromate concentration while the optimum condition predicted by ANN is at $\mathrm{pH} 6$ and $10 \mathrm{~g} / \mathrm{L}$ of NB concentration and of $60 \mathrm{ppm}$ of chromate concentration with chromate reduction (\%) of $75.13 \%$ and $96.27 \%$, respectively. The analysis by the ANN model shows better prediction data with a higher $\mathrm{R}^{2}$ value of 0.9991 and smaller average absolute deviation (AAD) and root mean square error (RMSE) of $0.33 \%$ and $0.302 \%$, respectively. Validation analysis showed the predicted values by RSM and ANN were close to the validation values, whereas the ANN showed the lowest deviation, 2.57\%, compared to the RSM. This finding suggests that the ANN showed a better prediction and fitting ability compared to the RSM for the nonlinear regression analysis. Based on this study, $A$. radioresistens $\mathrm{sp}$. NS-MIE exhibits strong potential characteristics as a candidate for the bioremediation of hexavalent chromium in the environment.
\end{abstract}

\section{Introduction}

Chromium is a type of heavy metal that is nowadays ubiquitously present in water, soil, and air. Heavy metals allude to metallic elements which have reasonably high density and possess harmful and toxic effects even at a very low concentration [1,2]. Chromium was initially founded in 1797 by a scientist named Louis Nicolas Vauguelin as a component in the red crystalline mineral crocoite $\left(\mathrm{PbCrO}_{4}\right)$. It was first described as a shiny grey metal that is unscented, hard crystalline, tasteless, and lustrous. Chromium is one of the elements in the transition group VIB besides tungsten and molybdenum in the twenty-fourth position of the periodic table [3]. Nearly $0.037 \%$ of the earth's crust is comprised of chromium making it as the seventh most abundant element in the earth. It is significantly more abundant than molybdenum, copper, lead, cobalt, zinc, and cadmium [4]. Chromium exists in several oxidation states ranging from +2 to +6 with the most stable being the trivalent and hexavalent chromium forms. Both trivalent and hexavalent chromium 
possess different biological effects. Trivalent chromium is a naturally occurring chromium and it is not harmful to living organisms while hexavalent chromium is carcinogenic and mobile as it can be transported through the cells via the sulphate and phosphate routes [5].

Throughout the last decades, hexavalent chromium has grown to be one of the major pollutants that contribute to the ecosystem's imbalance and substantial environmental problem due to its potential carcinogenicity and toxicity to human beings and living organisms [6]. This situation may arise as a result of rapid industrialization, especially in developing countries. Due to its lustrous and hardly corrosive characteristics, hexavalent chromium is used widely in various industries such as electroplating, inks, wood preservatives, textile dyeing, leather tanning, pigment production, refractories, and metal refining [7]. The high concentration of hexavalent chromium discharges as a result from industry is threatening the public health and quality of potable water. Therefore, the concentration of hexavalent chromium must be reduced and minimized to an acceptable and safe level. According to the US Environmental Protection Agency (EPA), the maximum contaminant level issued for total chromium is $100 \mu \mathrm{g} \mathrm{L}^{-1}$. For hexavalent chromium, the maximum concentration issued by the World Health Organization is $50 \mu \mathrm{g} \mathrm{L}^{-1}$ [6].

Numerous technologies and approaches have been studied and developed in the past to remove hexavalent chromium such as ion exchange, chemical precipitation, adsorption, and biosorption, electrodialysis, and reverse osmosis $[8,9]$. These technologies have been practiced for decades due to their efficacy. However, several disadvantages are arising from the utilization of these conservative approaches such as not economical and expensive to be operated in the long run, high energy requirements, and production of toxic discharge along with secondary effluent. Furthermore, some of them are not suitable and have low capacity to remediate low concentrations of hexavalent chromium [10]. Thereby, bioremediation has been introduced as one of the alternatives to remove heavy metals including hexavalent chromium.

Bioremediation is a biological process that remediates the environment through processes like adsorption, redox transformation, and precipitation reactions. Microorganisms such as bacteria, fungi, microalgae, and actinomycetes play a very vital and important role in reducing hexavalent chromium in bioremediation of industrial wastewater and contaminated soil. The reduction of hexavalent chromium by bacteria occurs aerobically, anaerobically, or both, relying on the factors affecting the reducing efficiency and the microbial species itself. Hexavalent chromium reducing aerobes usually employ NADH and endogenous cell reserves as their mechanism to reduce hexavalent chromium and hexavalent chromate-reducing anaerobes using the electron transport system containing cytochromes to reduce hexavalent chromium [11]. This biological technique of using microorganisms to reduce hexavalent chromium is a very fast and cost-effective process. Moreover, the utilization of microorganisms offers the reduction of hexavalent chromium at a very low concentration of chromium [12]. A large variety of bacteria have been reported for their ability in reducing and transforming hexavalent chromium to trivalent chromium under aerobic and anaerobic conditions such as Intrasporangium sp. Q5-1, Bacillus sp. ES29, Escherichia coli, Enterobacter cloacae, and Pseudomonas fluorescens LB300 [13].

It was proven that bioremediation by bacteria is one of the promising methods to remove heavy metals from wastewater or soil. The process is often affected by many parameters depending on the type of heavy metals, sample nature, and bacteria used. Therefore, the optimization process during bioremediation is one of the essential steps to achieve the best result. Response surface methodology (RSM) and artificial neural network (ANNs) are the examples of optimization tools that can be used to improve the bioremediation process. The conventional one factor at a time (OFAT) optimization methods that have been practiced since ages ago not only is laborious and time-consuming, but also does not show the overall interactions and effect of each parameter tested during the experiment and it may provide inaccurate data $[14,15]$.

RSM is one of the statistical and mathematical methods developed to overcome the issue as it can be used to measure the effects of numerous independent variables and the response of the experiment. It is beneficial to determine the effects of each variable alone or in combination [15]. This method serves many advantages such as the fact that it is time effective, is inexpensive, and provides an accurate and precise result. It is practical in the present study which is to optimize the $\mathrm{Cr}(\mathrm{VI})$ reduction by a newly isolated bacteria. This approach implements the low-order polynomial equation in a predetermined region of the variables and the equation will be assessed to obtain the optimum values of the variables tested for the best responses [14, 16, 17]. Besides RSM, artificial neural network (ANN) has also been broadly researched to optimize process because of its effective, robust, and prominent features in capturing the nonlinear relationships between parameters and response in a complex system. This method is very practical to be applied especially in a process requiring complex mechanisms to function, which is the case with the biological treatment process for heavy metals pollution. Thus, the employment of ANNs has gathered a growing interest in wastewater treatment control and modelling $[14,18]$. Quite an increasing number of researchers around the globe have started to employ RSM and ANN as tools to predict and optimize metal removal processes like the removal of $\mathrm{Cu}$ (II) by alkalimodified spent tea leaves [19] and the removal of $\mathrm{Pb}$ (II) by the nanocomposites of rice straw [20]. The results and data from the implementation of RSM and ANN were superior in their sensitivity analysis, generalization capabilities, and predictive efficiency in the bioremediation of heavy metals from wastewater and environment compared to OFAT alone $[14,15]$.

This study was carried out to isolate, characterize, and optimize chromate reduction from several chromatereducing bacteria from different agricultural soil samples. The availability of efficient hexavalent chromium reducing microorganisms is a crucial requirement for future bioremediation of agricultural soils contaminated with hexavalent 
chromium. It was discovered that most chromate-reducing bacteria were isolated from nonagricultural sources such as from industrial effluents and mining. Therefore, the isolation of a new potent strain is significant. The effect of $\mathrm{pH}$, type of media, media concentration, and hexavalent chromate concentration on chromate reduction by strain NS-MIE were optimized and modelled using two different approaches, RSM and ANN. Hopefully, the findings will provide a broad understanding of newly isolated chromate-reducing bacteria and provide alternative bacteria to bioremediate the hexavalent chromium in soils and water.

\section{Materials and Methods}

2.1. Isolation and Screening of Chromate-Reducing Bacteria. The chromate-reducing bacteria were isolated from two different soil sources which were agricultural soil and industrial soil. The bacteria from the agricultural soil were isolated from an oil palm plantation situated in Universiti Putra Malaysia (2.988208" N, 101.730392" E) and bacteria from industrial sources were isolated from the Juru Industrial Park, Pulau Pinang (5.316293” N, 100.430008” E). Soil from both sources were collected randomly and placed in a sterile Falcon tube. Then, $5 \mathrm{~g}$ of the soil was diluted in $100 \mathrm{~mL}$ of nutrient broth and incubated for $48 \mathrm{~h}$ on a $170 \mathrm{rpm}$ rotary shaker at $28^{\circ} \mathrm{C}$. After incubation, the broth was diluted using the serial dilution method and spread on nutrient agar supplemented with $20 \mathrm{ppm}, 50 \mathrm{ppm}$, and 100 ppm of $\mathrm{K}_{2} \mathrm{Cr}_{2} \mathrm{O}_{7}$ and incubated for $48 \mathrm{~h}$ at $28^{\circ} \mathrm{C}$. Next, a loop of the primary culture on the spread plate was streaked on nutrient agar plate supplemented with $50 \mathrm{ppm}$ of $\mathrm{K}_{2} \mathrm{Cr}_{2} \mathrm{O}_{7}$. The plates were incubated at $28^{\circ} \mathrm{C}$ for $24 \mathrm{~h}$ and continually streaked until pure colonies were obtained. Then, $1 \%$ of the original culture was aerobically grown overnight. $0.1 \mathrm{~mL}$ of the grown culture was inoculated in a $10 \mathrm{~mL}$ medium containing 50 ppm of $\mathrm{K}_{2} \mathrm{Cr}_{2} \mathrm{O}_{7}$. The mixtures were then incubated on a rotary shaker $(170 \mathrm{rpm})$ at $28^{\circ} \mathrm{C}$. After incubation, $1 \mathrm{~mL}$ of the sample was withdrawn aseptically and centrifuged at 10, 000 $\times \mathrm{g}$ for $10 \mathrm{~min}$. The supernatant of the sample was used to measure the chromate reduction rate using the 1,5-diphenyl carbazide method. A total of seven bacteria with the highest chromate reduction rate were further screened in a media supplemented with $100 \mathrm{ppm}$ of chromate.

\subsection{Molecular Identification of Chromate-Reducing Bacteria.} Pure bacteria colony exhibiting the highest chromate reduction was further identified using molecular identification method. 16s rRNA gene of the chosen isolate was amplified by PCR using universal forward primer and reverse primer. Then, it was analyzed for amplification using $1.2 \%$ agarose followed by electrophoresis at $70 \mathrm{~V}$ for one $\mathrm{h}$. The amplified 16s rRNA gene fragment was purified and sent to Apical Scientific Sdn. Bhd. for sequencing. The obtained 16s rRNA gene sequences were exported into "Basic Local Alignment Search Tool" (BLAST) from the website of the National Centre for Biotechnology Information (NCBI) to identify the highest match. The output of the BLAST sequences was sorted based on highly similar identity with other genus or species in the GenBank records. Next, the phylogenetic tree was constructed using MEGA software version 10.0 [21].

2.3. Screening of Chromate-Reducing Media. The bacterium chosen from the previous screening was further screened using different types of media. The media used in the screening were nutrient broth, Luria Bertani, and minimal salts media. The bacteria were incubated in each media that were initially supplemented with 50 ppm of $\mathrm{K}_{2} \mathrm{Cr}_{2} \mathrm{O}_{7}$ for 48 $\mathrm{h}$ on a $170 \mathrm{rpm}$ rotary shaker at $28^{\circ} \mathrm{C}$. All media used were autoclaved at $121^{\circ} \mathrm{C}, 15$ psi for $20 \mathrm{~min}$ before being used. The reduction rate was measured using the 1,5-diphenyl carbazide method at $24,48,72,96,120$, and $124 \mathrm{~h}$ after exposure.

2.4. Assaying Chromate Reduction by 1,5-Diphenylcarbazide. The activity of chromium reducing bacteria was measured by colorimetric changes using 1,5-diphenyl carbazide (Sigma, USA). The colorimetric reagent was prepared by dissolving $0.025 \mathrm{~g}$ in $100 \mathrm{~mL}$ of analytical grade acetone in order to minimize deterioration. Next, the hexavalent chromium in a grown culture was assayed by mixing $400 \mu \mathrm{l}$ of the culture supernatant with $400 \mu \mathrm{l}$ and $200 \mu \mathrm{l}$ of the colorimetric reagent in a $1 \mathrm{~mL}$ cuvette. The mixture was then further analyzed spectrophotometrically at $540 \mathrm{~nm}$ [22]

2.5. Optimization of Chromate Reduction by Response Surface Methodology (RSM). The optimization of the chromate reduction was carried out using response surface methodology (RSM). Three independent variables which were $\mathrm{pH}$, media concentration, and chromate concentration were chosen as the parameters with the reduction of chromate as a response of the experiment. All of the parameters were studied based on the range as stated in Table 1. The Box Behnken design was selected as the design to run all 17 optimization experiments.

The experiment was conducted in triplicate based on Table 2 with chromate reduction rate as the response of the experiment. Innoculation of $10 \mathrm{~mL}$ of the $1 \%$ original culture from 3, 6.5, and $10 \mathrm{~g} / \mathrm{L}$ of the nutrient broth containing 50, 75, and $100 \mathrm{ppm}$ of hexavalent chromium at different initial $\mathrm{pHs}$ were incubated for $24 \mathrm{~h}$ on a $170 \mathrm{rpm}$ rotary shaker at $28^{\circ} \mathrm{C}$. Tris and potassium phosphate buffers were used to regulate the $\mathrm{pH}$ of the media. After incubation, $1 \mathrm{~mL}$ of the sample was withdrawn aseptically and centrifuged at $10000 \times \mathrm{g}$ for $10 \mathrm{~min}$. The supernatant of the sample was used to measure the chromate reduction rate using the 1,5-diphenyl carbazide method [15].

2.6. Optimization of Chromate Reduction by Artificial Neural Network (ANN). The optimization of the chromium reducing activity by ANN was conducted using a commercial ANN software, NeuralPower version 2.5 (CPC$\mathrm{X}$ Software). The optimization was trained and tested by different types of the learning algorithm, which were backpropagation, Levenberg-Marquardt, and conjugate gradient methods before multilayer feed and multilayer full feedforward approaches were carried out. The network architecture consisted of an input layer with four neurons, an output 
TABLE 1: Upper limit and lower limit of Box Behnken Design.

\begin{tabular}{lcccc}
\hline Variables & \multirow{2}{*}{ Unit } & -1 & \multicolumn{2}{c}{ Range and level } \\
& & - & 0 & +1 \\
\hline $\mathrm{pH}$ & - & 7.5 & 6.5 & 10 \\
Media concentration & $\mathrm{g} / \mathrm{L}$ & 50 & 6.75 & 6 \\
Chromate concentration & $\mathrm{ppm}$ & 75 & 100 \\
\hline
\end{tabular}

TABLE 2: Design of Box Behnken.

\begin{tabular}{lccc}
\hline Run & $\begin{array}{c}\text { Nutrient Broth } \\
\text { Concentration } \\
{[\mathrm{g} / \mathrm{L}]}\end{array}$ & $\mathrm{pH}$ & Chromate concentration [ppm] \\
\hline 1 & 6.5 & 7.50 & 50 \\
2 & 10 & 6.00 & 75 \\
3 & 6.5 & 6.75 & 75 \\
4 & 6.5 & 6.00 & 50 \\
5 & 10 & 6.75 & 100 \\
6 & 3 & 6.00 & 75 \\
7 & 6.5 & 6.75 & 75 \\
8 & 6.5 & 6.00 & 100 \\
9 & 10 & 6.75 & 50 \\
10 & 3 & 7.50 & 75 \\
11 & 6.5 & 6.75 & 75 \\
12 & 3 & 6.75 & 50 \\
13 & 6.5 & 6.75 & 75 \\
14 & 6.5 & 7.50 & 100 \\
16 & 5.5 & 6.75 & 75 \\
\hline
\end{tabular}

layer with one neuron, and a hidden layer. Chromium concentration, $\mathrm{pH}$, and media concentration were used as network inputs and chromate reduction rate was used as the output. One hidden layer, number of neurons layers, and the transfer functions of hidden and output layers were used to develop several networks and to determine the optimal network topology. Each layer of the network was trained until the network root of mean square error (RMSE), average correlation coefficient $(\mathrm{R})$, and average determination coefficient were lower than 0.01 and equal to 1 and 1 , respectively [19].

\subsection{Determination of Optimum Point Using RSM and ANN.} The optimum point for chromate reduction by strain NS-MIE was determined and identified using RSM and ANN. In RSM, the approach involved the desires and priorities for every variable to figure out the relationship between chromium reduction rate and each of the variables involved [15]. Numerical optimization function in the Design Expert software recommended four optimum points with high desirability of the chromium reduction rate. In $\mathrm{ANN}$, the optimum points were determined by comparing three different algorithms which were particle swarm optimization, rotation inherit optimization, and genetic algorithm. Determination of the optimum conditions by each of the algorithm was carried out using NeuralPower version 2.5 (CPC-X Software). The parameters used were $\mathrm{pH}$, nutrient broth concentration, and chromate concentration. The predicted optimum condition by RSM and ANN was further validated, and the deviation from the optimum point was determined.

2.8. Comparative Error Analysis of RSM and ANN Models. Error analyses such as root mean square error (RMSE), correlation coefficients $\left(\mathrm{R}^{2}\right)$, standard error of prediction (SEP), and relative percent deviation (RPD) were calculated between experimental and predicted data of both RSM and ANN models. The formula used for error analysis was

$$
\begin{aligned}
R^{2} & =1-\frac{\sum_{i=1}^{n}\left(Y_{i . p}-Y_{i . e}\right)^{2}}{\sum_{i=1}^{n}\left(Y_{i . p-Y_{e}}\right)^{2}} \\
\mathrm{RMSE} & =\sqrt{\frac{\sum_{i=1}^{n}\left(Y_{i . p}-Y_{i . e}\right)^{2}}{n}} \\
\mathrm{SEP} & =\frac{R M S E}{Y_{e}} \times 100
\end{aligned}
$$




$$
\mathrm{RPD}=\frac{100}{n} \sum_{i=1}^{n} \frac{\left|\left(Y_{i . e}-Y_{i . p}\right)\right|}{\left|\left(Y_{i . e}\right)\right|}
$$

where $Y_{i . e}$ is the experimental data, $Y_{i . p}$ is the predicted data, $Y_{e}$ is the mean value of experimental data, and $\mathrm{n}$ is the number of the experimental data. The modelling ability of a given model is depending on the RMSE and SEP value as the lower the RMSE and SEP value, the higher the modelling ability. To evaluate the modelling abilities of the RSM and ANN models, the values predicted by RSM and ANN models were plotted against the corresponding experimental values.

\subsection{Effect of Different Initial Concentration of Hexava-} lent Chromium on Chromate Reduction Rate and Bacterial Growth. About $1 \%$ of the bacterial culture was aerobically grown overnight. Then, several $10 \mathrm{~mL}$ medium supplemented with different concentration of $\mathrm{K}_{2} \mathrm{Cr}_{2} \mathrm{O}_{7}(50,60,70,80$, $90,100,110,120$, and $160 \mathrm{ppm}$ ) were prepared in universal bottles. Exactly $0.1 \mathrm{~mL}$ of the grown culture was inoculated in each bottle containing the medium at the different initial concentration of $\mathrm{K}_{2} \mathrm{Cr}_{2} \mathrm{O}_{7}$. They were then incubated on a $170 \mathrm{rpm}$ rotary shaker at $28^{\circ} \mathrm{C}$. At every $2 \mathrm{~h}$ for the first $24 \mathrm{~h}, 1 \mathrm{~mL}$ of the sample was centrifuged at $10,000 \times \mathrm{g}$ and the supernatant was assayed and measured at $540 \mathrm{~nm}$. The growth of the bacterium was measured by diluting the pellet with distilled water and measured at $600 \mathrm{~nm}$. After the 24th $h$, the reading was taken every $6 \mathrm{~h}$ of the experiment until the 96 th $\mathrm{h}$. Media without inoculant but supplemented with same different initial concentration were used as negative control of the experiment.

\section{Results and Discussion}

3.1. Isolation, Identification, and Screening of Chromium Reducing Bacteria. Based on the biochemical analysis, the best chromate-reducing bacterium was a Gram-negative and aerobic bacterium. The bacterium needs oxygen to continuously grow and to fulfill its role to catalyze the hexavalent chromium bioreduction. The bacterium was identified as Acinetobacter radioresistens strain NS-MIE (Accession no. MK334657) by 16s bacterial sequencing. The phylogenetic analysis reveals that the NS-MIE strain originates from the A. radioresistens family through several genomic variations along with various generations with a high bootstrap value of $86 \%$ (Figure 1). None of the related strains from the phylogenetic analysis shows chromium resistant characteristic. This could happen on the account of genomic variations that took place along numerous genomic variation and modifications. The bacterium $A$. radioresistens sp. NS-MIE must have maintained its novel characteristics of chromium resistance and tolerance. The bacterium was chosen because it has the highest amount of chromium reduction rate in the screening process.

The broth containing soil from two different sources which were agricultural soil and industrial soil were spread on agar plates supplemented with 20,50 , and $100 \mathrm{ppm}$ of $\mathrm{K}_{2} \mathrm{Cr}_{2} \mathrm{O}_{7}$. The bacterial count from each plate decreases
TABLE 3: Percentage of chromate reduction of bacteria incubated in media supplemented with 100 ppm of $\mathrm{K}_{2} \mathrm{Cr}_{2} \mathrm{O}_{7}$.

\begin{tabular}{lccc}
\hline \multirow{2}{*}{ Bacterium } & \multicolumn{3}{c}{ Percentage of chromate reduction [\%] } \\
& 24th h & 48th h & 72nd h \\
\hline SS1 & 78.45 & 97.21 & 98.01 \\
SS6 & 72.56 & 81.23 & 92.33 \\
SS17 & 60.23 & 75.35 & 83.28 \\
SS21 & 74.21 & 85.25 & 92.43 \\
SS28 & 67.32 & 73.81 & 82.18 \\
SS34 & 66.12 & 70.23 & 79.98 \\
SS35 & 71.28 & 81.32 & 88.12 \\
\hline
\end{tabular}

*h: hour

with an increasing level of chromium causing sensitive microorganisms to cease growth on chromate-supplemented agar plates. This phenomenon was also reported by Das et al. [23]. From the agar plates integrated with chromate, a total of 40 bacteria of different colonies and morphologies were then further isolated in pure form and were subjected to assessment for relative chromate resistance.

For the primary screening, a total of 40 pure colonies were screened in nutrient broth incorporated with $50 \mathrm{ppm}$ of $\mathrm{K}_{2} \mathrm{Cr}_{2} \mathrm{O}_{7}$. The chromate reduction rate of all 40 colonies was measured spectrophotometrically after $48 \mathrm{~h}$ of incubation. From the result, it was found that only $17.5 \%$ of the tested bacteria were resistant and able to reduce more than $70 \%$ of $50 \mathrm{ppm} \mathrm{K} \mathrm{K}_{2} \mathrm{Cr}_{2} \mathrm{O}_{7}$ after $48 \mathrm{~h}$ of incubation. The tolerance of these 7 selected colonies were then screened secondarily in $100 \mathrm{ppm}$ of $\mathrm{K}_{2} \mathrm{Cr}_{2} \mathrm{O}_{7}$ to evaluate their ability to reduce chromium in high concentration and short duration. Based on the performance of these bacteria in reducing $100 \mathrm{ppm}$ of chromate, bacterium SS1, SS6, and SS21 were discovered to be appealing and promising because they reduce more than $90 \%$ of the chromate after $72 \mathrm{~h}$ of incubation (Table 3 ). Considering the rate of chromate reduction and the duration of the bacterium to reduce the chromate, isolate SS1 was chosen in this study.

3.2. Screening of Chromate-Reducing Media. Growth medium or culture medium is significant to assist the growth and sustainability of microorganisms. There are several types of media designed to be suitable for growing different types of microorganism. The types of the most common culture media used are nutrient broth, Luria Bertani, and minimal salt media. Each of these different media provides the nutrients needed for the microorganisms to sustain themselves, survive, and grow. They contain many ingredients enabling the media to be a favor to different types of microorganisms. Glycerol and glucose are frequently used as carbon sources for the microbes while nitrates and ammonium salts are employed as inorganic nitrogen sources of the media [24].

A. radioresistens sp. NS-MIE was grown in different types of media including nutrient broth, Luria Bertani, and minimal salt media to identify the types of media that is the best and most suitable for the bacterium to reduce hexavalent 


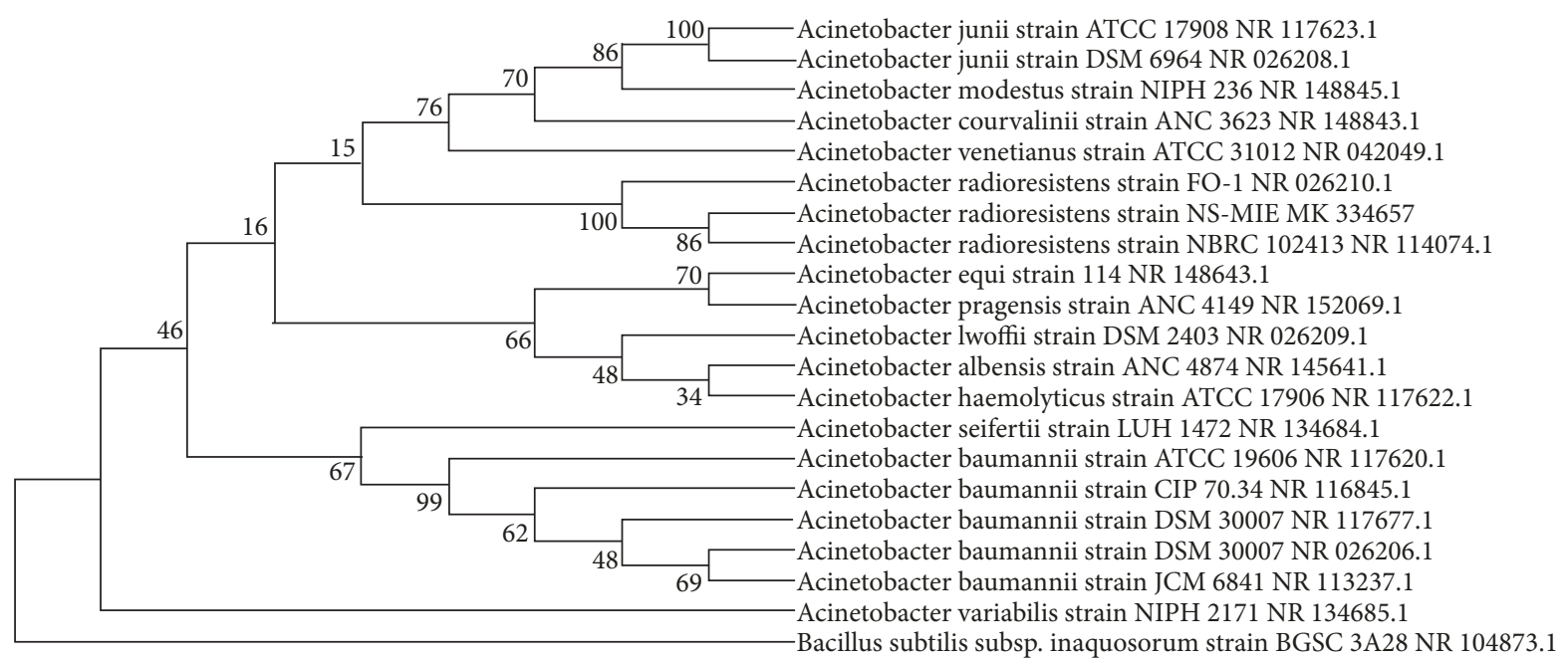

FIGURE 1: Phylogenic tree of A. radioresistens strain NS-MIE (Accesssion no: MK334657). The 16s rRNAs of A. radioresistens strain NS-MIE and Acinetobacter radioresistens strain NRBC 1024013 NR shows a high bootstrap value of $86 \%$.

TABLE 4: Screening of chromate-reducing media.

\begin{tabular}{lc}
\hline Media & Chromate reduction (\%) \\
\hline Nutrient Broth & 94.21 \\
Luria Bertani & 83.41 \\
\hline Minimal salt media & \\
Fructose & 9.42 \\
Galactose & 12.53 \\
Glucose & 16.11 \\
Maltose & 7.56 \\
Sucrose & 10.14 \\
Glycerol & 7.98 \\
Mannitol & 7.11 \\
Starch & 13.27 \\
Sodium acetate & 12.87 \\
\hline
\end{tabular}

chromium. Within 48 h of the incubation period, bacteria $A$. radioresistens sp. NS-MIE was able to reduce up to $94.21 \%$ and $83.41 \%$ of hexavalent chromium in nutrient broth and Luria Bertani, respectively (Table 4). These findings can be supported by many recent studies that used nutrient broth and Luria Bertani under an aerobic condition as the medium for the chromate-reducing medium $[2,25,26]$. Luria Bertani is a complex media and the utilization of Luria Bertani as a medium in chromate reduction is less favorable in some research. Besides that, the employment of minimal salt media for chromate-reducing bacteria was found to be effective but it requires a longer incubation period in order to reduce hexavalent chromium completely [27]. Considering all the significant aspects, the nutrient broth was chosen as the chromate-reducing media in this study.

3.3. Optimization of Chromate Reduction by Response Surface Methodology (RSM). Response surface methodology is a statistical tool that explains the relationship between multiple independent variables and one or more responses. It has been extensively used as a method to design experiments. This RSM technique is dependent on the fit of mathematical models like linear, quadratic models square polynomial function, and others [28]. In RSM experiments, the verification of the models was attained by means of statistical methods. This method can be utilized specifically to enhance the efficiency of the optimization experiment. The fundamental concept of the experimental design by RSM is to branch out all the vital considerations and merge the results via a mathematical model. The model can be employed for interpretations, predictions, and, most importantly, optimization. The optimization process by RSM is separated into six steps which are the assortment of the independent variables and responses, choosing the experimental design, carrying out the experiments and collection of data, fitting the model equation, analysis of variance, and determination of the optimal point [29].

In this study, optimization by RSM was carried out to procure a quadratic model of the bioreduction of the hexavalent chromium. The independent variables chosen for the study were $\mathrm{NB}$ concentration, $\mathrm{pH}$, and chromium concentration with chromium reduction rate as the responses of the experiment. The experimental and predicted results are represented in Table 6 . The predicted value of the experiment was obtained from an equation. The equation below has been derived from several regressions analyses to clarify the chromium reducing activity by bacteria $A$. radioresistens $\mathrm{sp}$. NS-MIE.

$$
\begin{aligned}
\mathrm{Y}= & 69.95+16.26 \mathrm{~A}-14.48 \mathrm{~B}-13.62 \mathrm{C}-2.52 \mathrm{AB} \\
& +0.44 \mathrm{AC}+1.36 \mathrm{BC}-8.42 \mathrm{~A} 2-1.62 \mathrm{~B} 2-3.52 \mathrm{C} 2
\end{aligned}
$$

$\mathrm{Y}$ in the equation refers to the predicted chromium reduction rate while $\mathrm{A}, \mathrm{B}$, and $\mathrm{C}$ are coded parameters for $\mathrm{NB}$ concentration, $\mathrm{pH}$, and chromium concentration, respectively. The ANOVA analysis was executed to evaluate the crucial effect of each of the single variables and combined variables 

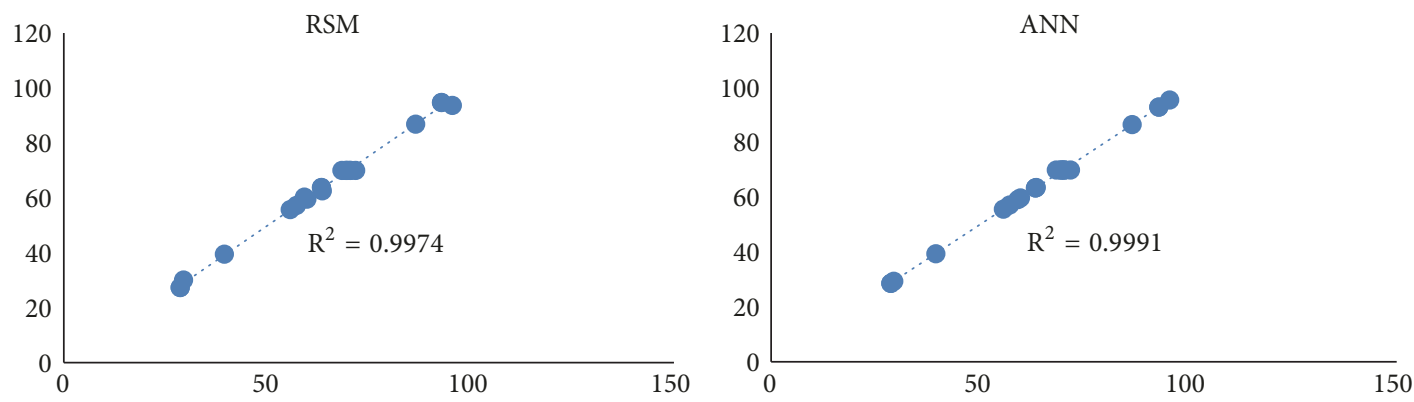

FIGURE 2: Actual versus RSM and ANN predicted values for chromium reduction by A. radioresistens strain NS-MIE.

(Table 5). Based on the ANOVA analysis, it is notable that the single variable of $\mathrm{A}$ ( $\mathrm{NB}$ concentration), B $(\mathrm{pH})$, and $\mathrm{C}$ (chromium concentration) was statistically significant with $\mathrm{p}<0.0001$. The combined variables of A2 were also statistically significant. The chromate reduction increases as the NB concentration increases, $\mathrm{pH}$ decreases, and chromium concentration decreases. The media containing $75 \mathrm{ppm}$ of chromium, $10 \mathrm{~g} / \mathrm{L} \mathrm{NB}$, and $\mathrm{pH} 6$ can enhance the chromate reduction up to $95.49 \%$. The regression model was significant with $\mathrm{p}<0.05$ and the $\mathrm{R}^{2}$ value of 0.9974 . The adjusted $\mathrm{R}^{2}$ value of the experiment is 0.9888 , implying that there is only a $2 \%$ variation of the chromium reduction activity by $A$. radioresistens that cannot be explained by this model. Moreover, the good correlation between the experimental and predicted value of the chromium reduction rate was also observed based on the adjusted $\mathrm{R}^{2}$ value that was close to 1 .

\subsection{Optimization of Chromate Reduction by Artificial Neural} Network (ANN). Artificial neural network (ANN) is a type of linear modelling techniques that has been widely used to explain a wide range of processes and mathematical objects. ANN procedures include the selection of a network architecture, determination of hidden layers and number of neurons in each layer, learning, training, and, lastly, validation and verification of the data [30]. In this study, ANN was utilized to model the chromium reduction rate by multilayer feedforward neural networks using QuickPropagation as the learning algorithm to determine the weight and biases [15]. Multilayer feedforward is a type of network that is commonly used and known in ANN modelling. These networks consist of three other types of layers which are input layer (independent variables), several hidden layers, and output layer (dependent variables). The inputs applied in this study were $\mathrm{NB}$ concentration, $\mathrm{pH}$, and chromium concentration while the output was chromium reduction rate. The number of the hidden layers between inputs and output has to be overcome by overfitting and overtraining to build a better ANN model. The result achieved from the experiment (Table 6) was used to build the model.

The experimental result of the chromium reduction by A. radioresistens sp. NS-MIE by RSM studied earlier was used randomly for training and testing. Based on Table 6, the bold form is the data used as a testing dataset (Table 7) for ANN modelling and the remaining data were used as a learning dataset (Table 8). Table 6 also displays the ANN predicted values for each experiment. The results of the ANN predicted values show a close correlation between the actual and the predicted values. This implies that the ANN result can fit the actual experimental data precisely. The relationship between actual experimental data and ANN predicted values can be viewed by plotting the experimental data versus ANN predicted. The value between actual and predicted ANN is close, signifying that the nonlinear fitting effects of the model are good. $\mathrm{R}^{2}$ and RSME values of the experiment were used to evaluate the accuracy of the model. The $\mathrm{R}^{2}$ value is 0.9998 which is very close to 1 , indicating that this model gives a good prediction. Figure 2 shows the comparisons between RSM and ANN experimental versus predicted value. From the graph plot, ANN shows better fitting with higher $\mathrm{R}^{2}$ value which also implies that ANN gives better optimization result compared to RSM study. To estimate and predict the responses, multiple layers of network and topologies were used to identify the exact number of neurons in the hidden layer between inputs and output layers. The ideal five ANN models are represented in Table 9.

3.5. Determination of Optimum Point Using RSM and ANN. The optimum points of $A$. radioresistens sp. NS-MIE to reduce hexavalent chromium were determined using RSM and ANN. This method uses priorities and desires to measure the relationship of every parameter involved with the chromium reduction rate as the response of the experiment. The optimum points predicted by RSM were determined by numerical optimization in the Design Expert software 6.01. The method displays the desirability value of 0.886 for the maximum chromate reduction rate by $A$. radioresistens $\mathrm{sp}$. NS-MIE. The maximum chromate reduction of $75.13 \%$ was achieved at the optimized condition of $10 \mathrm{~g} / \mathrm{L}$ of nutrient broth, $\mathrm{pH} 6$, and $100 \mathrm{ppm}$ of chromium concentration.

The prediction of the optimum point by ANN was done by three different algorithms which were genetic algorithm, rotation inherit optimization, and particle swarm optimization. The result shown in Table 10 reveals that there is no significant difference in values of chromium reduction rate predicted by the three different algorithms. The optimum point predicted by both RSM and ANN shows close agreement between the experimental and the predicted values implying that the obtained model is adequate to optimize the 
TABle 5: Analysis of variance (ANOVA).

\begin{tabular}{lccccc}
\hline Sources & Sum of squares & df & Mean squares & F-value & P>F \\
\hline Model & 5697.40 & 9 & 633.04 & 158.45 & $<0.0001$ \\
A-Nutrient broth & 2116.31 & 1 & 2116.31 & 529.69 & $<0.0001$ \\
B-pH & 1677.11 & 1 & 1677.11 & 419.77 & $<0.0001$ \\
C-Chromate conc. & 1483.92 & 1 & 1483.92 & 371.41 & $<0.0001$ \\
AB & 25.42 & 1 & 25.42 & 6.36 & 0.0397 \\
AC & 0.76 & 1 & 0.76 & 0.19 & 0.6755 \\
BC & 7.40 & 1 & 7.40 & 1.85 & 0.2158 \\
A $^{2}$ & 298.19 & 1 & 298.19 & 74.63 & $<0.0001$ \\
B $^{2}$ & 11.06 & 1 & 11.06 & 2.77 & 0.1401 \\
C $^{2}$ & 52.07 & 1 & 52.07 & 13.03 & $0.0086 *$ \\
Residual & 27.97 & 7 & 4.00 & 4.61 & 0.0869 \\
Lack of Fit & 21.69 & 3 & 7.23 & & $\mathrm{R}^{2}$ \\
Pure Error & 6.27 & 4 & 1.57 & & Not significant \\
& & & & & 0.9974 \\
\end{tabular}

$* \mathrm{P}>\mathrm{F}$ less than $0.05=$ statistically significant.

TABLE 6: Central composite design matrix for the three independent variables with the observed and predicted response for chromium reduction by $A$. radioresistens sp. NS-MIE.

\begin{tabular}{|c|c|c|c|c|c|c|}
\hline \multirow{2}{*}{ Run } & \multirow{2}{*}{$\begin{array}{c}\text { NB conc. } \\
{[\mathrm{g} / \mathrm{l}]}\end{array}$} & \multirow{2}{*}{$\mathrm{pH}$} & \multirow{2}{*}{$\begin{array}{c}\mathrm{Cr}[\mathrm{VI}] \text { conc. } \\
{[\mathrm{ppm}]}\end{array}$} & \multicolumn{3}{|c|}{$\mathrm{Cr}[\mathrm{VI}]$ reduction [\%] } \\
\hline & & & & Observe response & RSM predicted & ANN predicted \\
\hline 1 & 6.5 & 7.50 & 50 & 63.5663 & 62.60 & 63.566 \\
\hline 2 & 10 & 6.00 & 75 & 95.4913 & 93.18 & 95.491 \\
\hline 3 & 6.5 & 6.75 & 75 & 71.7557 & 69.95 & 69.952 \\
\hline 4 & 6.5 & 6.00 & 50 & 92.8957 & 94.27 & 92.896 \\
\hline 5 & 10 & 6.75 & 100 & 59.7617 & 61.10 & 59.762 \\
\hline 6 & 3 & 6.00 & 75 & 55.6473 & 55.61 & 55.647 \\
\hline 7 & 6.5 & 6.75 & 75 & 68.3594 & 69.95 & 69.952 \\
\hline 8 & 6.5 & 6.00 & 100 & 63.3438 & 64.31 & 63.344 \\
\hline 9 & 10 & 6.75 & 50 & 86.5347 & 87.47 & 86.535 \\
\hline 10 & 3 & 7.50 & 75 & 29.3827 & 31.69 & 29.383 \\
\hline 11 & 6.5 & 6.75 & 75 & 69.4251 & 69.95 & 69.952 \\
\hline 12 & 3 & 6.75 & 50 & 57.1515 & 55.81 & 57.151 \\
\hline 13 & 6.5 & 6.75 & 75 & 70.3893 & 69.95 & 69.952 \\
\hline 14 & 6.5 & 7.50 & 100 & 39.4539 & 38.08 & 39.454 \\
\hline 15 & 6.5 & 6.75 & 75 & 69.8326 & 69.95 & 69.952 \\
\hline 16 & 3 & 6.75 & 100 & 28.6329 & 27.70 & 28.633 \\
\hline 17 & 10 & 7.50 & 75 & 59.1438 & 59.18 & 59.144 \\
\hline
\end{tabular}

TABLE 7: Testing dataset for ANN modelling.

\begin{tabular}{lcccc}
\hline Run & NB conc. $(\mathrm{g} / \mathrm{L})$ & $\mathrm{pH}$ & $\mathrm{Cr}(\mathrm{VI})$ conc. $(\mathrm{ppm})$ & $\mathrm{Cr}(\mathrm{VI})$ reduction $(\%)$ \\
\hline 4 & 6.5 & 6.00 & 50 & 92.8957 \\
8 & 6.5 & 6.00 & 100 & 63.3438 \\
11 & 6.5 & 6.75 & 75 & 69.4251 \\
13 & 6.5 & 6.75 & 75 & 70.3893 \\
16 & 3.0 & 6.75 & 100 & 28.6329 \\
\hline
\end{tabular}


TABLE 8: Learning data set for ANN modelling.

\begin{tabular}{lcccc}
\hline Run & NB conc. $(\mathrm{g} / \mathrm{L})$ & $\mathrm{pH}$ & $\mathrm{Cr}(\mathrm{VI})$ conc. $(\mathrm{ppm})$ & $\mathrm{Cr}(\mathrm{VI})$ reduction $(\%)$ \\
\hline 1 & 6.5 & 7.5 & 50 & 63.5663 \\
2 & 10 & 6.0 & 75 & 95.4913 \\
3 & 6.5 & 6.75 & 75 & 71.7557 \\
5 & 10 & 6.75 & 100 & 59.7617 \\
6 & 3 & 6.0 & 75 & 55.6473 \\
7 & 6.5 & 6.75 & 75 & 68.3594 \\
9 & 10 & 6.75 & 50 & 86.5347 \\
10 & 3 & 7.5 & 75 & 29.3827 \\
12 & 3 & 6.75 & 50 & 57.1515 \\
14 & 7.5 & 100 & 39.4539 \\
15 & 6.5 & 6.75 & 69.8326 \\
17 & 6.5 & 7.5 & 75 & 59.1438 \\
\hline
\end{tabular}

TABLE 9: Summary of active networks.

\begin{tabular}{|c|c|c|c|c|c|c|c|c|}
\hline Model & $\begin{array}{l}\text { Learning } \\
\text { algorithm }\end{array}$ & $\begin{array}{c}\text { Connection } \\
\text { type }\end{array}$ & $\begin{array}{c}\text { Transfer } \\
\text { function } \\
\text { output }\end{array}$ & $\begin{array}{c}\text { Transfer } \\
\text { function } \\
\text { hidden }\end{array}$ & $\begin{array}{c}\text { Training set } \\
\text { R2 }\end{array}$ & RSME & Testing set R2 & RMSE \\
\hline $3-20-1$ & QP & MNFF & Tanh & Tanh & 0.99945 & 0.626 & 0.99985 & 0.345 \\
\hline $3-20-1$ & $\mathrm{QP}$ & MNFF & Tanh & Sigmoid & 0.99345 & 0.826 & 0.92985 & 0.245 \\
\hline $3-20-1$ & $\mathrm{QP}$ & MNFF & Tanh & Linear & 0.99145 & 0.926 & 0.91985 & 0.545 \\
\hline
\end{tabular}

TABLE 10: Validation of the optimization values predicted by RSM and ANN.

\begin{tabular}{lccccc}
\hline Model & Algorithm & NB conc $[\mathrm{g} / \mathrm{L}]$ & $\mathrm{pH}$ & $\begin{array}{c}\text { Chromate } \\
\text { conc. } \\
{[\mathrm{ppm}]}\end{array}$ & Predicted RSM/ANN [\%] \\
\hline RSM & Desirability function & 10.0 & 6.0 & 100.0 & 75.13 \\
\hline ANN & Genetic algorithm & 10.0 & 6.0 & 60.17 & 96.26 \\
& Rotation inherit optimization & 10.0 & 6.0 & 60.18 & 96.26 \\
& Particle swarm optimization & 10.0 & 6.0 & 61.19 & 96.25 \\
\hline
\end{tabular}

chromium reduction by $A$. radioresistens sp. NS-MIE. Both RSM and ANN can be concluded as the appropriate model to use for prediction and optimization process.

3.6. 3D Dimensional Analysis. Figures 3 and 4 show the response surface plot showing the effect of interactions between the three variables on chromate reduction by $A$. radioresistens $\mathrm{sp}$. NS-MIE by RSM and ANN. The 3D contour plots represent the interactive effect of two variables at one time by keeping the value of the other parameter. The interaction involved in the study was the interaction between nutrient broth concentration with $\mathrm{pH}$, nutrient broth concentration with chromium concentration, and chromium concentration with $\mathrm{pH}$. The elliptical shape of the contour displays that there is an interaction between those particular parameters. When there is no interaction between the parameters, the $3 \mathrm{~d}$ contour plot shows a circular or round shape.

Both the RSM and ANN response surface plots show similar patterns of interaction between each of the parameters. The interaction between $\mathrm{pH}$ and $\mathrm{NB}$ concentration shows that chromium reduction rate was increased with an increasing amount of $\mathrm{NB}$ concentration and $\mathrm{pH}$ value of the medium. According to a study by Fan et al. [31], low $\mathrm{pH}$ is favorable in hexavalent chromium reducing activities because it aids in the redox reaction of the aqueous phase and it helps the proton to participate in the following reaction:

$$
\mathrm{HCrO}_{4}=+7 \mathrm{H}^{+}+3 \mathrm{e} 4 \mathrm{Cr} 3^{+}+4 \mathrm{H} 2 \mathrm{O}
$$

The interaction between NB concentration and chromium concentration shows that, with the increasing amount of chromium concentration and decreasing amount of NB concentration, the chromium removal rate seems to be increasing. From the plot, it can be seen that NB concentration in the range from 8 to $10 \mathrm{~g} / \mathrm{L}$ brought chromium reduction rate to a stable increasing pattern. The interaction between $\mathrm{pH}$ and chromium concentration displays a declining chromium reduction rate with the increasing $\mathrm{pH}$ values and chromium concentration. This is explained earlier by the interaction between $\mathrm{NB}$ concentration and $\mathrm{pH}$ where low $\mathrm{pH}$ is stated to be more preferable due to the redox reaction. 


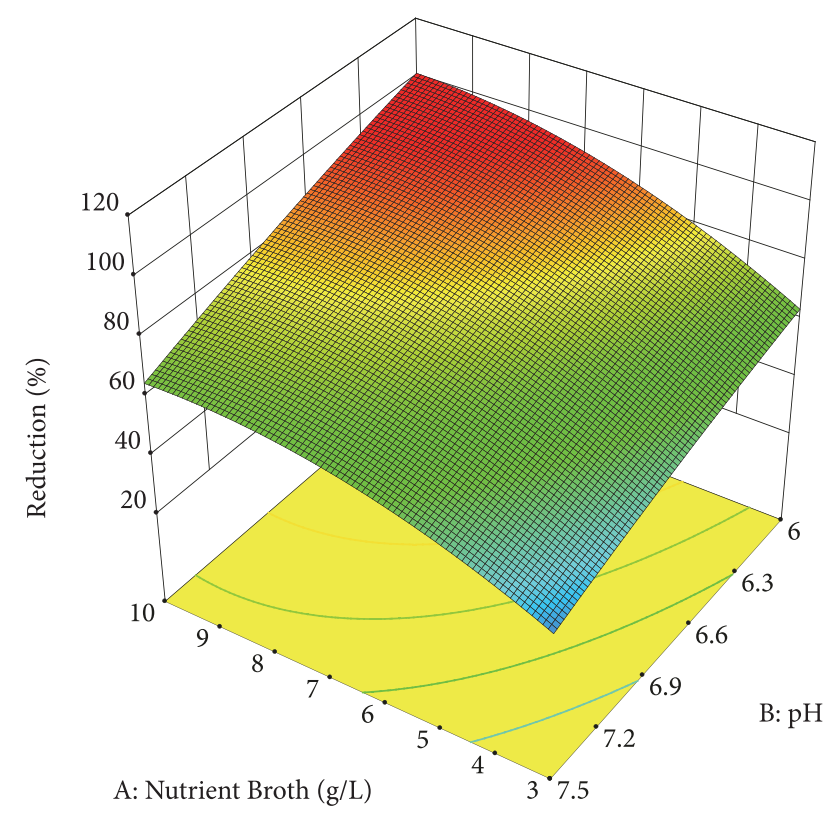

(a)

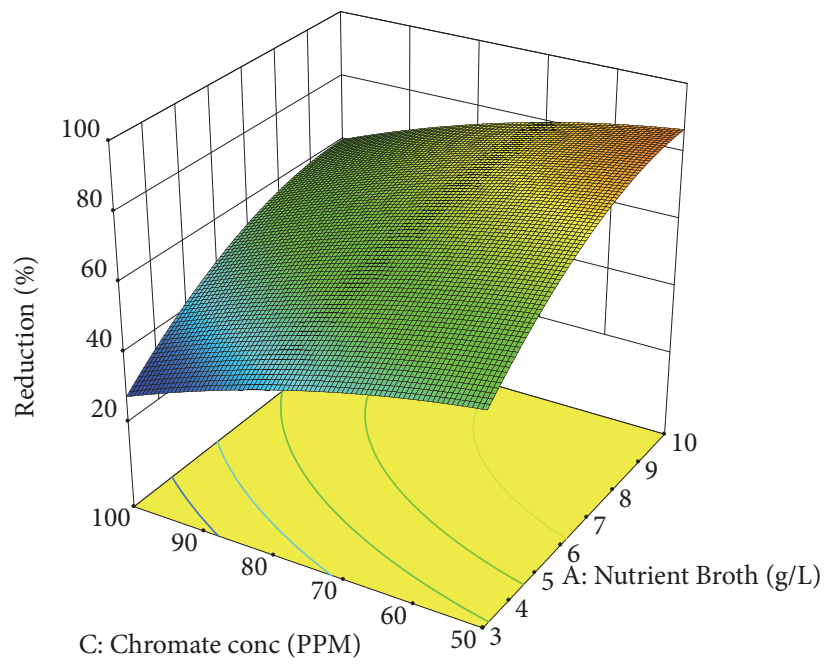

(b)

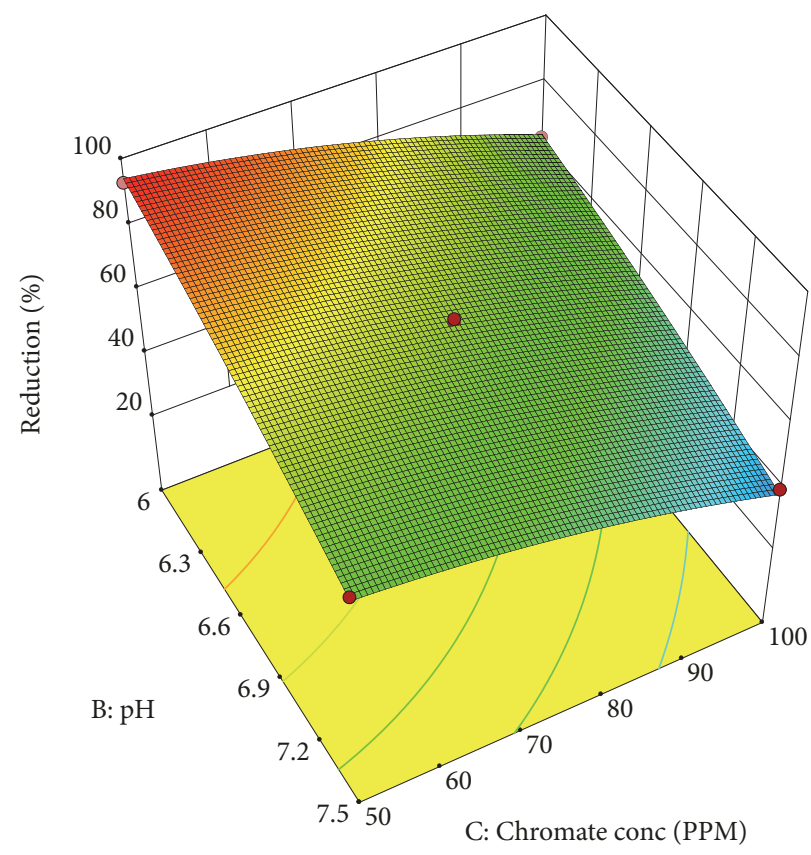

(c)

FIGURE 3: Three-dimensional surface curve on the interaction between three independent variables by RSM. Surface interaction curve between, (a) NB concentration versus $\mathrm{pH}$, (b) NB concentration versus chromium concentration, and (c) $\mathrm{pH}$ versus chromium concentration.

3.7. Comparative Error Analysis of RSM and ANN Models. Table 11 represents the comparative error analysis of the RSM and ANN models. The root mean square error (RMSE), correlation coefficients $\left(\mathrm{R}^{2}\right)$, standard error of prediction (SEP), and relative percent deviation (RPD) were obtained from evaluating the experimental and predicted values of both models. The comparative error analysis was made to verify the prediction accuracy and generalization capacity of both models in optimizing the $\mathrm{Cr}(\mathrm{VI})$ removal by $A$. radioresistens.
The correlation coefficients $\left(\mathrm{R}^{2}\right)$ for the RSM and ANN models were 0.9974 and 0.991 , respectively, indicating that the ANN model shows better regression and fitting compared to RSM (Figure 2). The high $\mathrm{R}^{2}$ value also reveals that only \pm $0.1 \%$ of the data cannot be explained by the models of both RSM and ANN. The RSME values in Table 9 indicate the absolute fit of the model. The standard error prediction (SEP), also known as sums of square error, and the relative percent deviation (RPD) show greater value for RSM as compared to 

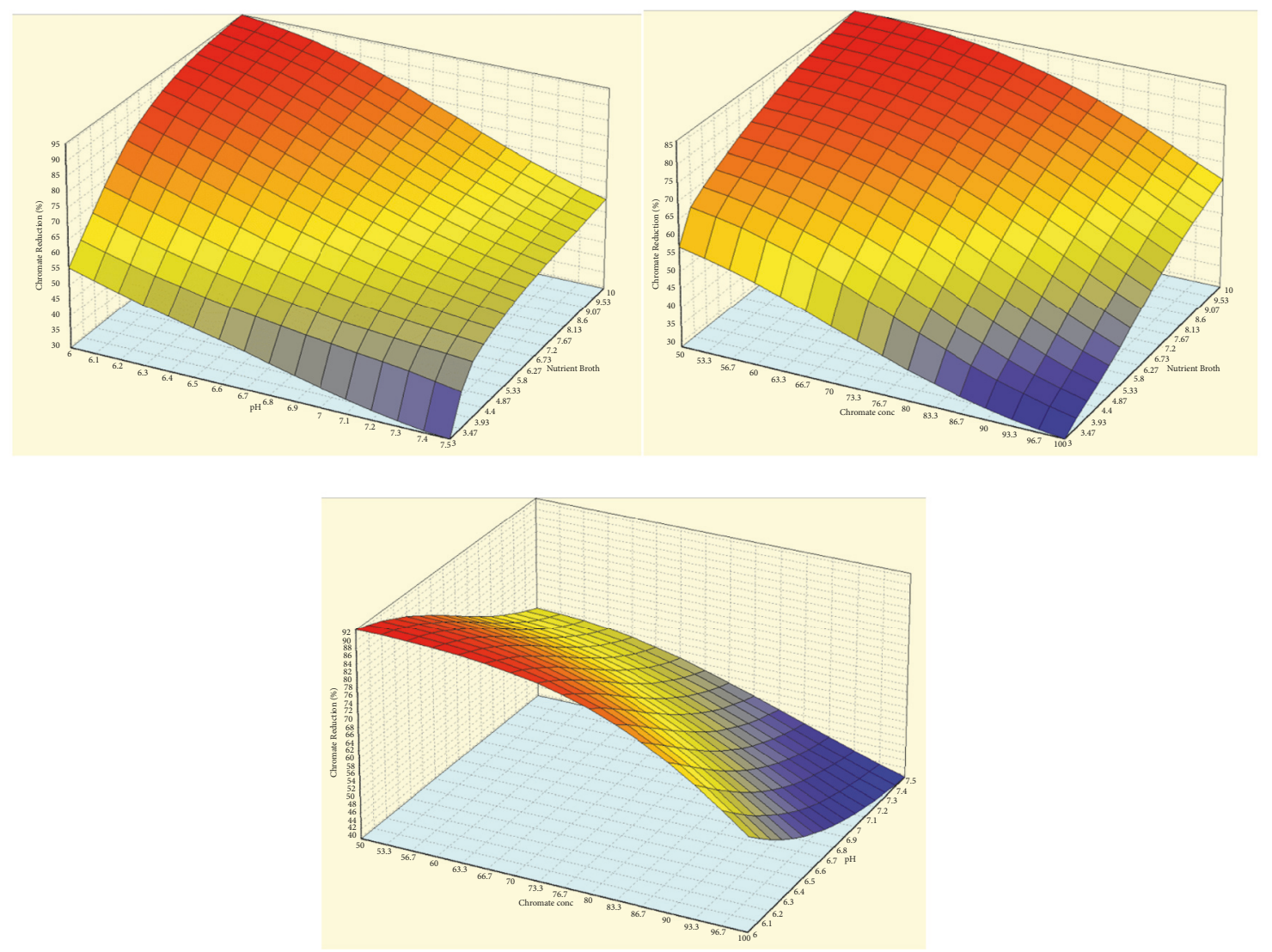

FIGURE 4: ANN response surface for three different independent variables. Response surface between NB concentration versus pH, NB concentration versus chromium concentration, and $\mathrm{pH}$ versus chromium concentration.

TABLE 11: Comparative error analysis of RSM and ANN models.

\begin{tabular}{lccrr}
\hline & Error & & MSM & Model \\
& & RMSE & 0.6781 & 0.302 \\
\hline Root mean square error & $\mathrm{R}^{2}$ & 0.9974 & 0.9991 \\
Correlation coefficients & SEP (\%) & 2.1900 & 0.3300 \\
Standard error of prediction & RPD (\%) & 1.9984 & 2.5700 \\
Relative percent deviation & & & \\
\hline
\end{tabular}

ANN. This indicates that RSM model prediction has a greater deviation in comparison to the prediction made by the ANN model. It also means that the ANN model provides better fitting and higher accuracy in predicting the percentage of $\mathrm{Cr}(\mathrm{VI})$ reduction by $A$. radioresistens. Some studies made in the past that used to compare the utilization of RSM and ANN approaches in removing heavy metals such as the removal of lead from leachate using red mud [32] and removal of copper by alkali-modified spent tea leaves [19] also reported that $\mathrm{ANN}$ is a better approach as an optimization tool.

\subsection{Effect of Hexavalent Chromium Concentration on the} Percentage of Chromate Reduction and Bacterial Growth. The effect of chromium concentration on the percentage of chromate reduction and bacterial growth is significant in the study because it implies the tolerance level of the bacteria to chromium. The bacterium was grown aerobically in NB media supplemented with nine different initial concentrations of the chromium (50 to $160 \mathrm{ppm}$ ). In this study, the bacterium $A$. radioresistens strain NS-MIE has the ability to reduce $90 \%$ to $99 \%$ of 50 and 60 ppm hexavalent chromium within the first $24 \mathrm{~h}$ (Figure 5). Within the next $48 \mathrm{~h}$, the bacterium reduces $95 \%$ and $85 \%$ of 70 ppm and 80 ppm of hexavalent chromium, respectively. Finally, 90 and 100 ppm of hexavalent chromium were reduced completely in the next $78 \mathrm{~h}$ of the experiment. A. radioresistens strain NS-MIE can reduce up to $39 \%$ of the $160 \mathrm{ppm}$ chromium. However, the chromate-reducing activity seems to be stagnant without any significant increase after $48 \mathrm{~h}$ of the incubation period. The bacterium is incapable of reducing the hexavalent chromium completely starting from the hexavalent concentration of 110 ppm and above. The percentage of chromate reduction is 


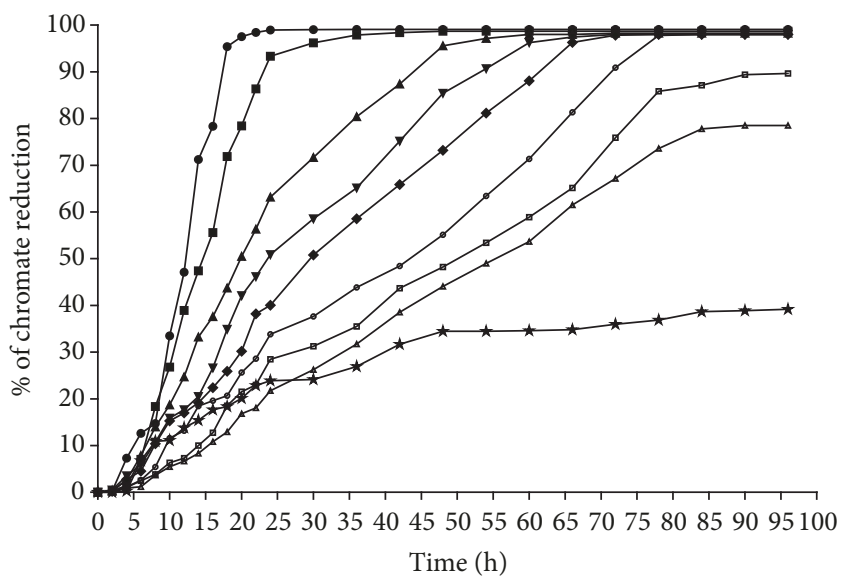

$$
\begin{aligned}
& \rightarrow 50 \mathrm{ppm} \\
& -60 \mathrm{ppm} \\
& \leftarrow 70 \mathrm{ppm} \\
& -80 \mathrm{ppm} \\
& \rightarrow-90 \mathrm{ppm} \\
& \rightarrow-100 \mathrm{ppm} \\
& -110 \mathrm{ppm} \\
& -120 \mathrm{ppm} \\
& \leftarrow 160 \mathrm{ppm}
\end{aligned}
$$

Figure 5: Effect of different initial concentration of hexavalent chromium on chromate reduction rate. The percentage of chromate reduction seems to decrease as the concentration of the hexavalent chromium increase. The chromate reduction rate seems to remain stagnant at certain value starting from the hexavalent chromium concentration of $110 \mathrm{ppm}$ and above.

stagnant after a certain amount of incubation time, which might be due to the inhibition of chromate reductase in $A$. radioresistens, thereby affecting the capability of the bacterium to reduce $\mathrm{Cr}(\mathrm{VI})$ at the higher concentration [33].

The effect of chromium concentration was further evaluated by measuring bacterial growth every $6 \mathrm{~h}$ from the initial point of the experiment until the growth reaches a stationary phase. From the experiment, it was observed that the bacterial growth keeps decreasing as the hexavalent chromium concentration increases (Figure 6). In the media containing 50 and $60 \mathrm{ppm}$ of hexavalent chromium, $A$. radioresistens strain NS-MIE's growth continuously rose with a growth rate that was double its initial point at the first $48 \mathrm{~h}$ of incubation. At $160 \mathrm{ppm}$, the bacterium grew very slowly and finally reached the stationary phase after $78 \mathrm{~h}$ of incubation. Most studies regarding the bacterial kinetics in the presence of $\mathrm{Cr}(\mathrm{VI})$ show fair increasing values of bacteria growth during the initial period of the experiment. This might be because microorganisms usually develop resistance to certain types of heavy metals and they are metabolically adapting to the presence of heavy metals in their surroundings during acclimatization [34]. Some studies reported that the metal ion damaged the existing enzyme in the microorganisms and the enzyme will be replaced with a new metabolically adapted enzyme $[35,36]$. However, the effect of the acclimatization might not be seen after a certain amount of time. This happens because, in the presence of elevated $\mathrm{Cr}(\mathrm{VI})$, growth is inhibited resulting in a decreased amount of bacterial growth [34].

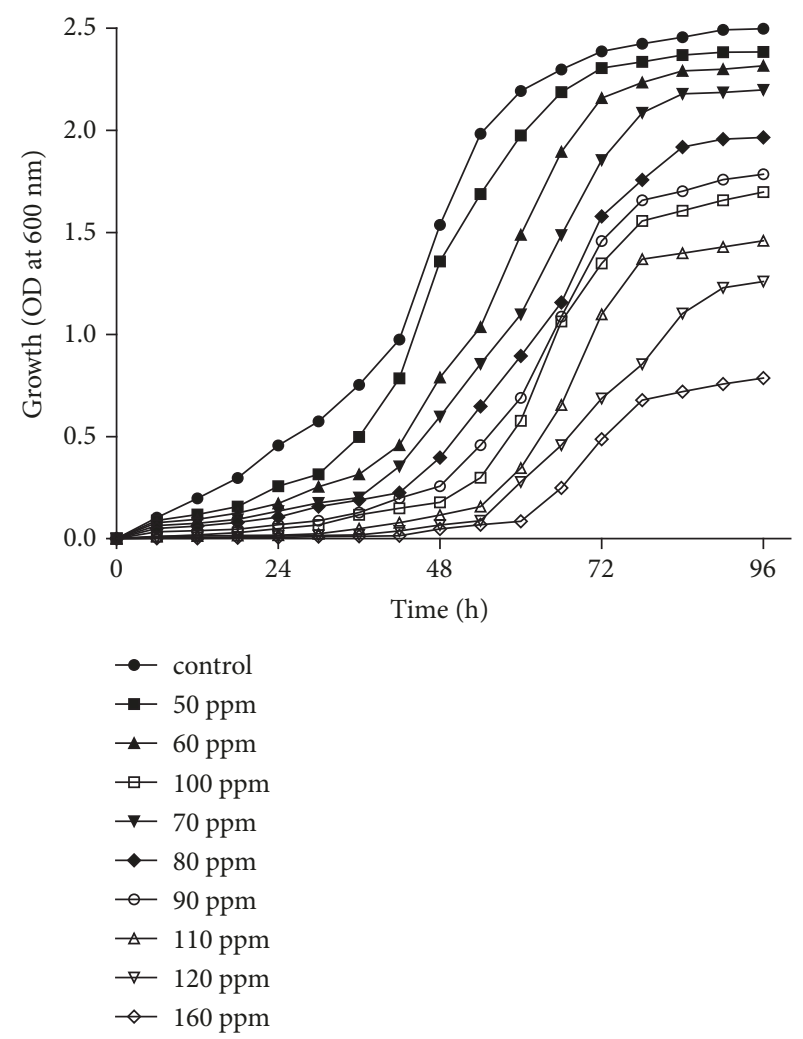

FIgUre 6: Optical density of $A$. radioresistens strain NS-MIE at different concentrations of hexavalent chromium.

\section{Conclusions}

The newly isolated bacterium $A$. radioresistens sp. NS-MIE shows and offers strong potential in reducing hexavalent chromium even at a high concentration of hexavalent chromium. The bacterium exhibits high tolerance and resistance in NB supplemented with $160 \mathrm{ppm}$ of $\mathrm{K}_{2} \mathrm{Cr}_{2} \mathrm{O}_{7}$ but only reduces hexavalent chromium up to $94.75 \%$ under the optimum conditions. The optimization of chromium reduction by the bacterium $A$. radioresistens sp. NS-MIE by RSM and ANN was successfully executed, and it was found that optimization by ANN gives better estimation point and data fitting as compared to RSM. Thus, it is envisioned that the bacterium provides a promising potential to be utilized in bioremediation of chromium-contaminated sites and the biological treatment of wastewater.

\section{Data Availability}

The data used to support the findings of this study are available from the corresponding author upon request.

\section{Conflicts of Interest}

The authors declare that there are no conflicts of interest regarding the publication of this paper. 


\section{Acknowledgments}

This project was financed by funds from Putra Grant (GPIPM /2017/9532800) and Yayasan Pak Rasyid Grant UPM (6300893-10201).

\section{References}

[1] H. Daraei, A. Mittal, J. Mittal, and H. Kamali, "Optimization of $\mathrm{Cr}(\mathrm{VI})$ removal onto biosorbent eggshell membrane: experimental \& theoretical approaches," Desalination and Water Treatment, vol. 52, no. 7-9, pp. 1307-1315, 2014.

[2] S. Mishra and R. N. Bharagava, "Toxic and genotoxic effects of hexavalent chromium in environment and its bioremediation strategies," Journal of Environmental Science and Health - Part C Environmental Carcinogenesis and Ecotoxicology Reviews, vol. 34, no. 1, pp. 1-32, 2016.

[3] B. Chakraborty, S. Indra, D. Hazra, R. Betai, L. Ray, and S. Basu, "Performance study of chromium (VI) removal in presence of phenol in a continuous packed bed reactor by escherichia coli isolated from east Calcutta wetlands," BioMed Research International, vol. 2013, Article ID 373412, 8 pages, 2013.

[4] S. Gunatilake, "Methods of removing heavy metals from industrial wastewater," Methods, vol. 1, no. 1, 2015.

[5] V. S. Protsenko and F. I. Danilov, "Chromium electroplating from trivalent chromium baths as an environmentally friendly alternative to hazardous hexavalent chromium baths: Comparative study on advantages and disadvantages," Clean Technologies and Environmental Policy, vol. 16, no. 6, pp. 1201-1206, 2014.

[6] B. Qiu, C. Xu, D. Sun et al., "Polyaniline coating on carbon fiber fabrics for improved hexavalent chromium removal," $R S C$ Advances, vol. 4, no. 56, pp. 29855-29865, 2014.

[7] R. Khosravi, M. Fazlzadehdavil, B. Barikbin, and A. A. Taghizadeh, "Removal of hexavalent chromium from aqueous solution by granular and powdered Peganum Harmala," Applied Surface Science, vol. 292, pp. 670-677, 2014.

[8] Y. Kim, H. Joo, N. Her et al., "Simultaneously photocatalytic treatment of hexavalent chromium $(\mathrm{Cr}(\mathrm{VI}))$ and endocrine disrupting compounds (EDCs) using rotating reactor under solar irradiation," Journal of Hazardous Materials, vol. 288, pp. 124-133, 2015.

[9] C. Wang and Y. Cui, "Recognition of a New Cr(VI)-Reducing Strain and Study of the Potential Capacity for Reduction of Cr(VI) of the Strain," BioMed Research International, vol. 2019, 9 pages, 2019.

[10] D. Mamais, C. Noutsopoulos, I. Kavallari et al., "Biological groundwater treatment for chromium removal at low hexavalent chromium concentrations," Chemosphere, vol. 152, pp. 238244, 2016.

[11] M. Ahemad, "Bacterial mechanisms for $\mathrm{Cr}(\mathrm{VI})$ resistance and reduction: An overview and recent advances," Folia Microbiologica, vol. 59, no. 4, pp. 321-332, 2014.

[12] L. J. DeFilippi, "Bioremediation of hexavalent chromium in water, soil, and slag using sulfate-reducing bacteria," in Remediation of Hazardous Waste Contaminated Soils, pp. 455-476, Routledge, 2018.

[13] M. S. Sanjay, D. Sudarsanam, G. A. Raj, and K. Baskar, "Isolation and identification of chromium reducing bacteria from tannery effluent," Journal of King Saud University - Science, 2018.

[14] T. Shojaeimehr, F. Rahimpour, M. A. Khadivi, and M. Sadeghi, "A modeling study by response surface methodology (RSM) and artificial neural network (ANN) on $\mathrm{Cu} 2+$ adsorption optimization using light expended clay aggregate (LECA)," Journal of Industrial and Engineering Chemistry, vol. 20, no. 3, pp. 870-880, 2014.

[15] S. N. A. Sanusi, M. I. E. Halmi, S. R. S. Abdullah, H. A. Hassan, F. M. Hamzah, and M. Idris, "Comparative process optimization of pilot-scale total petroleum hydrocarbon (TPH) degradation by Paspalum scrobiculatum L. Hack using response surface methodology (RSM) and artificial neural networks (ANNs)," Ecological Engineering, vol. 97, pp. 524-534, 2016.

[16] D. C. Montgomery, Design and Analysis of Experiments, John Wiley \& Sons, 2017.

[17] T. Şahan, H. Ceylan, N. Şahiner, and N. Aktaş, "Optimization of removal conditions of copper ions from aqueous solutions by Trametes versicolor," Bioresource Technology, vol. 101, no. 12, pp. 4520-4526, 2010.

[18] N. G. Turan, B. Mesci, and O. Ozgonenel, "Artificial neural network (ANN) approach for modeling $\mathrm{Zn}$ (II) adsorption from leachate using a new biosorbent," Chemical Engineering Journal, vol. 173, no. 1, pp. 98-105, 2011.

[19] A. Ghosh and K. Sinha, "Optimization of reduction of copper using stenotrophomonas maltophilia pd2 biomass and artificial neural network modeling," Environmental Engineering \& Management Journal, vol. 14, no. 1, 2015.

[20] R. Khandanlou, H. R. Fard Masoumi, M. B. Ahmad, K. Shameli, M. Basri, and K. Kalantari, "Enhancement of heavy metals sorption via nanocomposites of rice straw and $\mathrm{Fe} 3 \mathrm{O} 4$ nanoparticles using artificial neural network (ANN)," Ecological Engineering, vol. 91, pp. 249-256, 2016.

[21] L. Y. Chai, S. H. Huang, Z. H. Yang, B. Peng, Y. Huang, and Y. H. Chen, "Hexavalent chromium reduction by Pannonibacter phragmitetus BB isolated from soil under chromiumcontaining slag heap," Journal of Environmental Science and Health, Part A: Toxic/Hazardous Substances and Environmental Engineering, vol. 44, no. 6, pp. 615-622, 2009.

[22] N. A. Sopian, "Isolation, Characterization and Growth Optimization of a Chromate-reducing Bacterium," Bioremediation Science and Technology Research, vol. 2, no. 2, pp. 18-24, 2015.

[23] S. Das, J. Mishra, S. K. Das et al., "Investigation on mechanism of $\mathrm{Cr}(\mathrm{VI})$ reduction and removal by Bacillus amyloliquefaciens, a novel chromate tolerant bacterium isolated from chromite mine soil," Chemosphere, vol. 96, pp. 112-121, 2014.

[24] V. Madhavi, A. V. B. Reddy, and K. G. Reddy, "An overview on research trends in remediation of chromium," Research Journal of Recent Sciences, vol. 2277, p. 2502, 2013.

[25] M. Megharaj, S. Avudainayagam, and R. Naidu, "Toxicity of hexavalent chromium and its reduction by bacteria isolated from soil contaminated with tannery waste," Current Microbiology, vol. 47, no. 1, pp. 51-54, 2003.

[26] M. Ilias, I. M. Rafiqullah, B. C. Debnath, K. S. B. Mannan, and M. M. Hoq, "Isolation and characterization of chromium(VI)reducing bacteria from tannery effluents," Indian Journal of Microbiology, vol. 51, no. 1, pp. 76-81, 2011.

[27] R. N. Bharagava and S. Mishra, "Hexavalent chromium reduction potential of Cellulosimicrobium sp. isolated from common effluent treatment plant of tannery industries," Ecotoxicology and Environmental Safety, vol. 147, pp. 102-109, 2018.

[28] R. Minjares-Fuentes, A. Femenia, M. C. Garau, J. A. MezaVelázquez, S. Simal, and C. Rosselló, "Ultrasound-assisted extraction of pectins from grape pomace using citric acid: a response surface methodology approach," Carbohydrate Polymers, vol. 106, no. 1, pp. 179-189, 2014. 
[29] R. H. Myers, D. C. Montgomery, and C. M. Anderson-Cook, Response surface methodology: process and product optimization using designed experiments, John Wiley \& Sons, Inc., New York, NY, USA, 2016.

[30] K. Gurney, An Introduction to Neural Networks, CRC Press, 2014.

[31] L. Fan, C. Luo, M. Sun, and H. Qiu, "Synthesis of graphene oxide decorated with magnetic cyclodextrin for fast chromium removal," Journal of Materials Chemistry, vol. 22, no. 47, pp. 24577-24583, 2012.

[32] F. Geyikçi, E. Kiliç, S. Çoruh, and S. Elevli, "Modelling of lead adsorption from industrial sludge leachate on red mud by using RSM and ANN," Chemical Engineering Journal, vol. 183, pp. 5359, 2012.

[33] A. R. Shakoori, M. Makhdoom, and R. U. Haq, "Hexavalent chromium reduction by a dichromate-resistant gram-positive bacterium isolated from effluents of tanneries," Applied Microbiology and Biotechnology, vol. 53, no. 3, pp. 348-351, 2000.

[34] A. S. Stasinakis, D. Mamais, N. S. Thomaidis, and T. D. Lekkas, "Effect of chromium(VI) on bacterial kinetics of heterotrophic biomass of activated sludge," Water Research, vol. 36, no. 13, pp. 3341-3349, 2002.

[35] C. F. Gokcay and U. Yetis, "Effect of chromium(VI) on activated sludge," Water Research, vol. 25, no. 1, pp. 65-73, 1991.

[36] S. Chang, J. Huang, and Y. Liu, "Effects of Cd(II) and Cu(II) on a Biofilm System," Journal of Environmental Engineering, vol. 112, no. 1, pp. 94-104, 1986. 


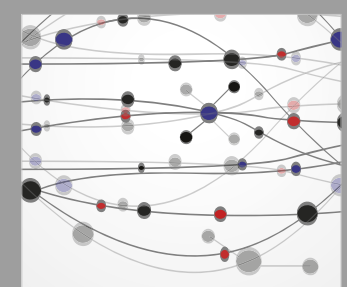

The Scientific World Journal
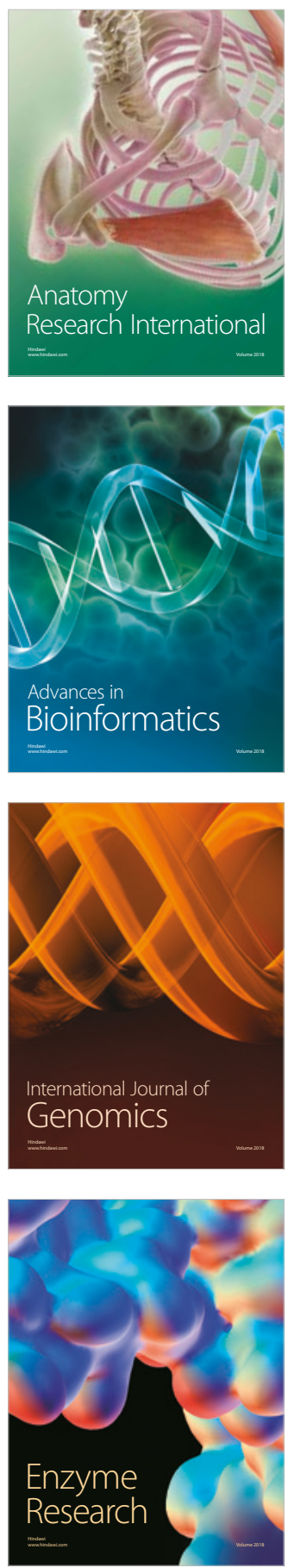
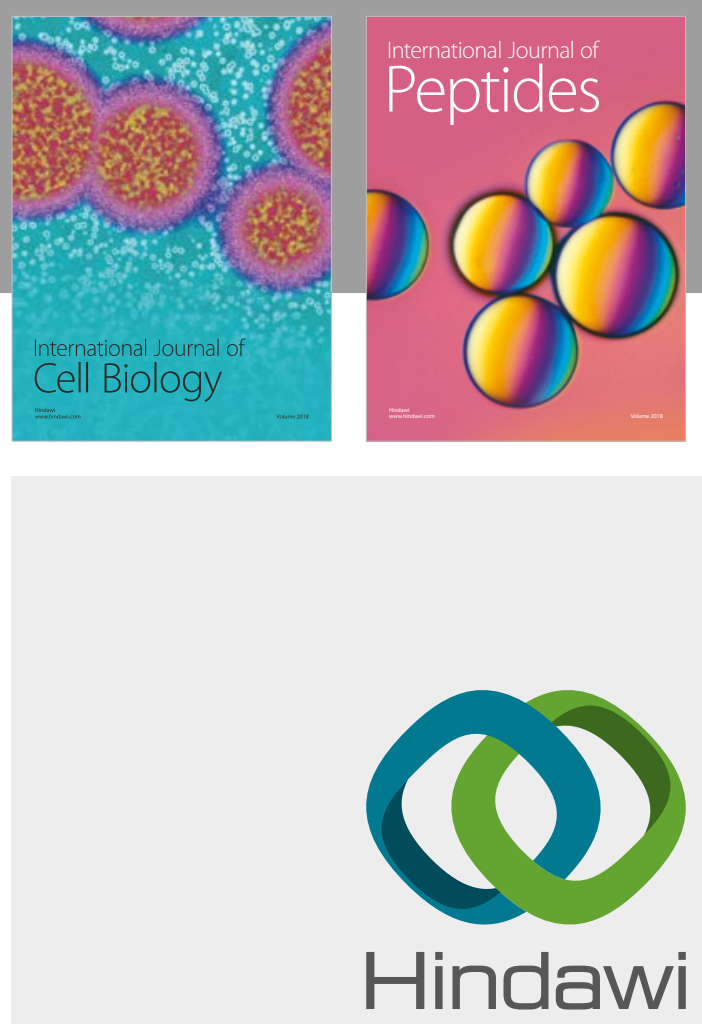

Submit your manuscripts at

www.hindawi.com
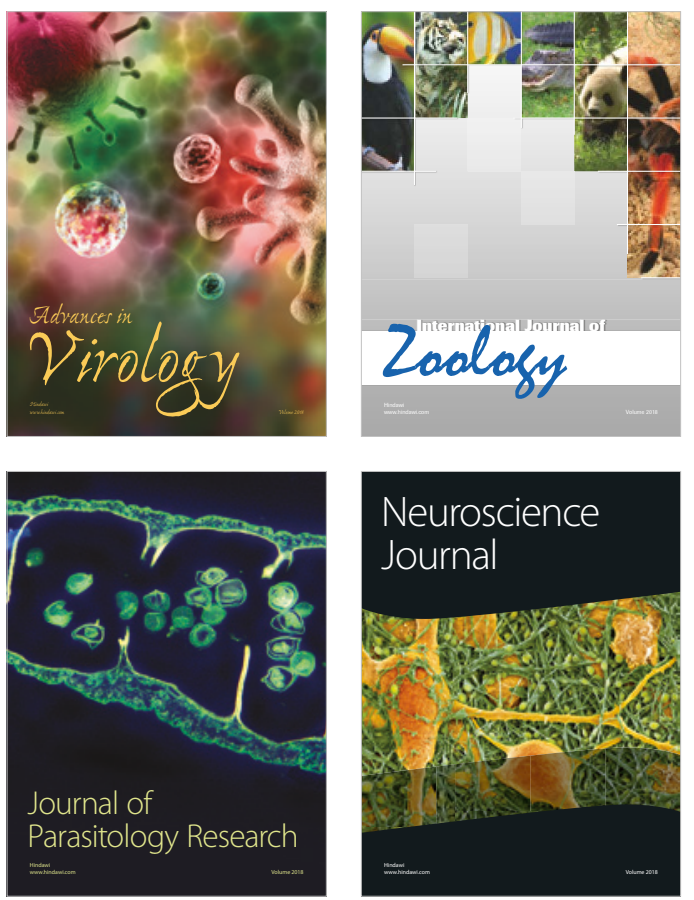
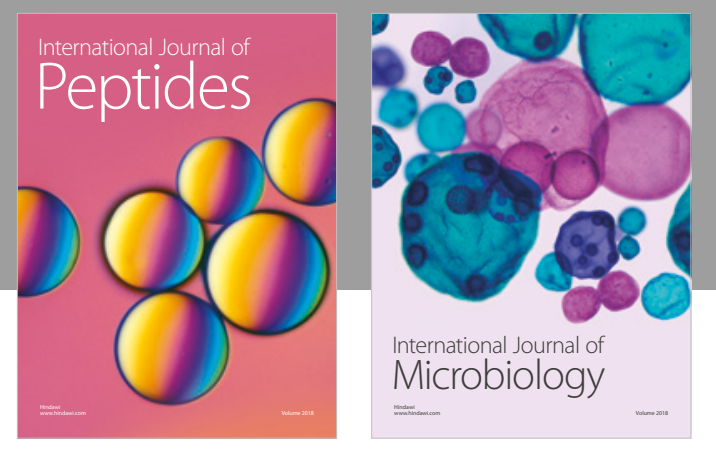

nternational Journal of Microbiology
Journal of
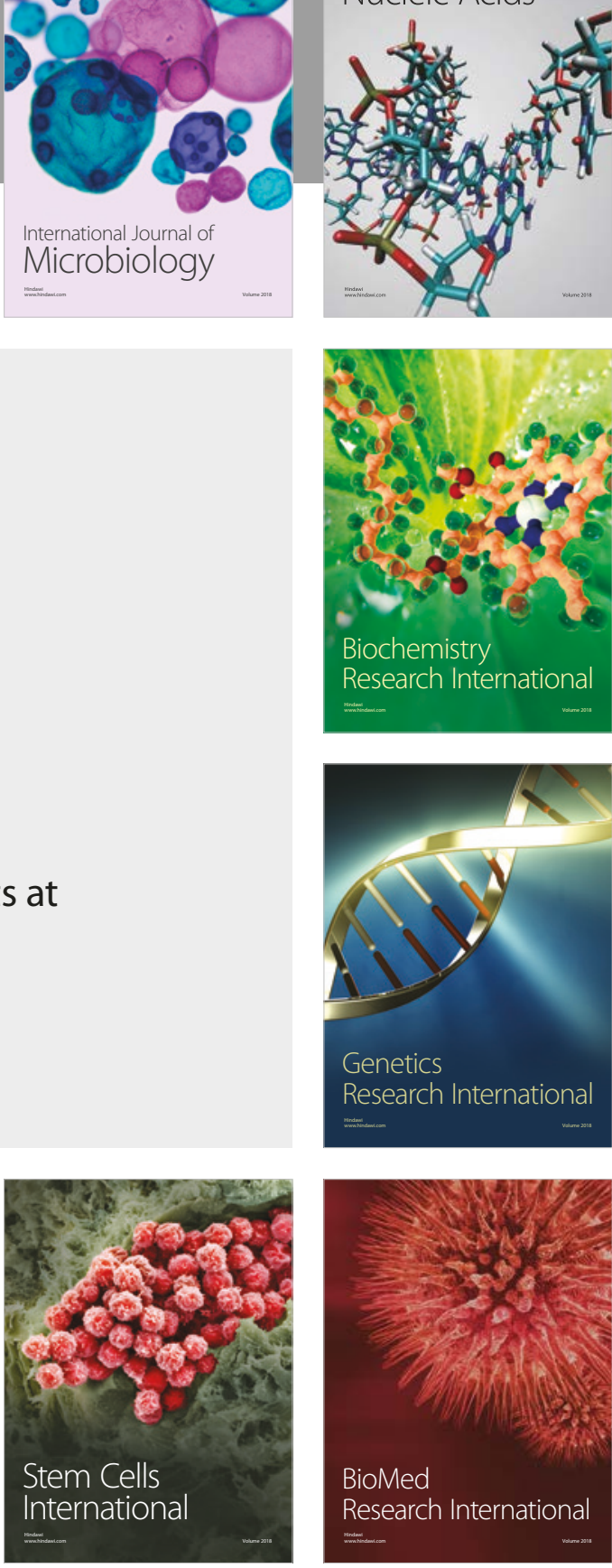
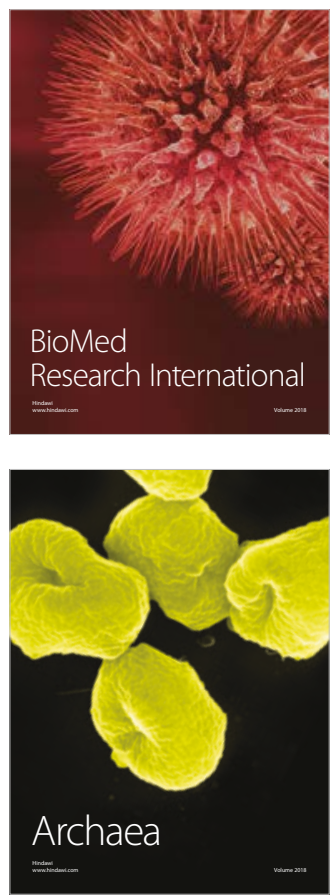